\title{
Some Aspects of the 1982-83 Brazilian Payments Crisis
}

BRAZIL's post-1973 economic performance was regarded with admiration in 1979, both in Brazil and elsewhere. Although real GNP growth had declined from the spectacular levels of 1971-73 (around 12 percent a year), it registered more than 8 percent during 1974-76 and nearly 6 percent during 1977-79. The sketchy and somewhat mysterious Brazilian national accounts even registered a post-1973 increase in the rate of fixed capital formation: from 22.9 percent of GNP during 1971-73, it rose to 26.1 percent during 1974-76, declining to 24.9 percent during 1977-79. The share of gross domestic saving in GNP rose during 1974-76, relative to the previous three-year period, although it fell below the 1971-73 level during 1977-79. ${ }^{1}$

Inflation accelerated after 1973, interrupting a declining trend, and large current account deficits occurred during 1974-79. Yet the growth rate of the external debt, defined as gross medium- and long-term public and publicly guaranteed debt, between the end of 1973 and the end of 1979 ( 25.8 percent a year) was not that far above the annual growth rate of merchandise exports (20.5 percent a year between 1971-73 and 197779). It could be argued in 1979 that, while some Brazilian investment

Whatever insights may be found in this paper can be traced back to my colleagues at the Department of Economics, Pontifical Catholic University of Rio de Janeiro. I thank Edmar L. Bacha, Guillermo Calvo, Paulo Nogueira Batista, Jr., Laurence M. Weiss, and members of the Brookings Panel for their comments.

1. These shares have been calculated using data expressed in 1970 prices. Unless otherwise stated, data in this paper are from Banco Central do Brasil, Relatório 1982 (Brasilia: Departmento Econômico do Banco Central do Brasil, 1983), and Boletim Mensal, vol. 19 (March 1983); and Fundação Getulio Vargas, Conjuntura, vol. 37 (May 1983), and previous issues of those publications. 
projects seemed to be based on optimistic scenarios (for example, exports of steel and petrochemicals during the 1980s, breakthroughs in "gasohol" technology, large demands for both hydroelectric and atomic energy), real borrowing costs in international markets made even marginal projects appear worthwhile.

During 1979 the Shah of Iran was overthrown, Paul Volcker was appointed head of the Federal Reserve Board, and a new president came to power in Brazil. A policy debate arose within the new Brazilian administration. Although pledged to gradual democratization, the regime remained quite authoritarian, so the operational debate occurred within a narrow circle of government technocrats, with the rest of the nation, including opposition economists, looking on or talking among themselves. One group of government technocrats argued that it was time to slow the pace of growth, probably more to cool inflation than to reduce the expansion of debt. Perhaps the case was made in 1979 that it was time to correct distortions accumulated since 1973, not the least of which was the reluctance to adjust domestic oil prices to international levels. Between 1973 and 1978 the volume of petroleum imports increased by almost 40 percent while domestic crude petroleum production during 1979 was slightly below that for $1973 .^{2}$ It could have been pointed out that net external debt (gross debt minus international reserves) grew at 36.7 percent a year between 1973 and 1979, a rate almost double that of merchandise exports.

The prudent planners, led by Mario Henrique Simonsen, were routed by the formidable Antonio Delfim Netto, whose association with the "miracle years" of 1968-73 earned him great popularity with entrepreneurs and generals, and even the reluctant admiration of some opposition economists. A new administration that pledged (gradual and controlled) democratization found retrenchment unpalatable. Public opinion and many of the opposition economists, although unconsulted, probably found the commitment to high growth more congenial than the almost "un-Brazilian" pessimism of the cautious technocrats. In August 1979 Simonsen resigned as minister of planning, and Delfim Netto replaced him.

The paper is organized as follows. The next section sketches what a

2. Antonio Carlos Lemgruber, Paulo Nogueira Batista, Jr., and Roberto Fendt, Jr., Choques Externos e Respostas de Política Econômica do Brasil: O Primeiro Choque do Petróleo (Rio de Janeiro: Editora da Fundação Getulio Vargas, 1981), p. 15. 
prudent planner's balance-of-payments outlook might have been in 1979. These counterfactual projections are then contrasted with what actually happened during the first three years of this decade. Even a summary evaluation of Brazilian indebtedness and performance during recent years must rely on ideas raised by growth, macroeconomic, and industrial organization theories. After contrasting 1980-82 balance-of-payments reality with the counterfactual projections, peculiarities of Brazilian macroeconomics are discussed, with references to long-term growth strategy. The organization of international financial markets and its consequences for the Brazilian crisis are analyzed next. The tortuous Brazilian relations with the International Monetary Fund are also examined in that context. The paper closes with a number of observations about Brazilian performance and policy.

\section{The Prudent Planner's Counterfactual Projections}

At the end of 1979 Brazil's gross external debt reached $\$ 49.9$ billion, while international reserves were $\$ 9.7$ billion; at that time there was little reason to doubt the rough accuracy of either number, a credibility that was to be lost during the early 1980s. Debt of less than one year of maturity, excluded from the former amount, was not perceived as unusual, and may be estimated at $\$ 7.5$ billion. Merchandise exports during 1979 reached $\$ 15.2$ billion and expanded to $\$ 20.1$ billion in 1980 ; few government technocrats regarded a ratio of debt to exports of about 3:1 as unmanageable. Merchandise imports during 1979 and 1980 were $\$ 18.1$ and $\$ 23.0$ billion, respectively; a ratio of reserves to annual imports of almost 1:2 was regarded as quite satisfactory. Plausible estimates of the ratio of debt to GNP or to the total Brazilian capital stock did not appear alarming (except, perhaps, to some-but not all-opposition economists). Contrary to 1983 conventional wisdom, few considered the growth of debt to be out of line with the growth of the stock of direct foreign investment in Brazil; the latter grew between the end of 1973 and the end of 1979 at an average annual rate of 23 percent a year, not far below the growth of gross debt. It is therefore very doubtful that those who lost the 1979 policy debate intended to stop the growth of debt completely. In what follows, it is assumed that the prudent planner, acquainted with growth theory, would have tried to limit the growth of 
net debt to the expected interest rate relevant to Brazil in world markets. This assumption probably exaggerates the caution of the defeated 1979 planners, but it helps to bring out key points in the Brazilian story of the early 1980s.

Between 1971-73 and 1977-79, Brazilian import dollar prices grew at an annual rate somewhat above 14 percent, while export dollar prices grew at an annual rate somewhat below 14 percent. The Brazilian terms of trade deteriorated by 10 percent between 1971-73 and 1974-76, recovering during 1977-79. A prudent planner in 1979 could have counted on another terms-of-trade deterioration of 10 percent after the second oil shock, without a foreseeable recovery. Bearing in mind that a CarterVolcker team in the United States was likely to continue during the early 1980 s, the following annual percentage increases in international prices could have been expected:

$\begin{array}{lcc} & 1980 & 1981 \text { and later } \\ \text { Import dollar prices } & 25.0 & 10.0 \\ \text { Export dollar prices } & 12.5 & 10.0\end{array}$

During 1974-79 Brazil paid average dollar interest rates that, calculated on either gross or net debt, were substantially below the growth of its dollar import and export prices (the gross average is 9.8 percent; the net is 11.5 percent; average LIBOR was 8.4). ${ }^{3}$ By late 1979 a worried borrower might have feared a return to positive real rates of interest, at least after the 1980 adjustment to the second oil shock. An expected nominal rate of interest for Brazil of 12.5 percent, and an equal growth in the gross and net debt, are assumed in the counterfactual projections presented below. Those projections could have anticipated in 1979 that prudent bankers would supply the required funds at the indicated interest rate.

What about export volume? Its growth after 1973 remained remarkably high and reasonably steady: it averaged more than 7 percent a year

3. The numbers have been calculated by averaging the implicit annual interest rates. These rates were obtained by comparing actual interest payments (either gross or net) with the debt (either gross or net) for the end of the previous year. If the implicit rates are calculated using the contemporaneous midyear debt (estimated as a simple average of the end-of-the-year debts), the gross average becomes 8.7 percent, and the net, 9.7 percent. These latter numbers, especially the gross interest estimate, yield unrealistically low spreads over LIBOR, the London Interbank Offer Rate. A share of Brazilian international reserves during these years was held in assets earning little or no interest; gold holdings averaged 1.4 million fine troy ounces. 
from 1971-73 to 1974-76, and about 5 percent a year between the latter date and 1977-79. It was not unreasonable in 1979 to project a 6 percent annual growth in export volume for the early 1980s, assuming the maintenance of policies of small devaluations and export subsidies, which had kept export incentives roughly constant in real terms during the 1970s. Below I address the geographic composition of exports; in 1979 this was not perceived as a serious issue. It is noteworthy that the projected growth rate in the dollar value of merchandise exports exceeded the expected interest rate and the growth of debt, but not by much.

For other items in the balance of payments an annual growth rate of 16 percent in nominal values is assumed; this is the post-1980 expected annual growth in the value of merchandise exports, a conservative figure relative to the 1973-79 experience. Nominal imports, and their volume, are obtained as residuals. A balance-of-payments projection that began with borrowing estimates and ended with allowable imports would have been regarded as peculiar and "upside down" in 1979; yet it was to become the methodology of the Brazilian government and of the International Monetary Fund during the last quarter of 1982.

The results of the counterfactual exercise are presented in table 1, which also shows the actual data for 1979 , a year when the overall balance of payments showed a deficit of $\$ 3.2$ billion. Perhaps the most striking result is the required contraction in the volume of merchandise imports, which even by 1983 does not recover to its 1979 level. A comparison of the counterfactual projection of import volume for 1980 82 with that actually registered during 1977-79 reveals a decline of 18 percent. It may be argued that this projection goes beyond prudence in at least one respect: the implied ratio of international reserves to imports rises from about 0.54 in 1979 (comparing end-of-the-year reserves with imports for that year) to 0.67 in 1980 and declines thereafter to 0.61 in 1983. Imposing a 1:2 ratio of reserves to imports, however, would make available for imports only an additional $\$ 1.4$ billion a year at current prices, not enough to change the broad picture of real import decline sketched in table 1 . Such an assumption, of course, would imply a decline in the ratio of reserves to gross debt. ${ }^{4}$ Similar results would apply to less stringent borrowing limits.

4. The sharp swings experienced during the early 1980 s in external short-term trade credits have highlighted the significance of reserve-import ratios, especially for oil importers. A country with a 0.5 ratio of reserves to imports could continue importing for 
Table 1. The Prudent Planner's Counterfactual Projections for the Brazilian Balance of Payments, 1980-83

Millions of dollars

\begin{tabular}{|c|c|c|c|c|c|}
\hline \multirow[b]{2}{*}{ Item } & \multirow{2}{*}{$\begin{array}{c}\text { Actual, } \\
1979\end{array}$} & \multicolumn{4}{|c|}{ Projected } \\
\hline & & 1980 & 1981 & 1982 & 1983 \\
\hline Merchandise exports ${ }^{b}$ & 15,244 & 18,064 & 20,954 & 24,307 & 28,196 \\
\hline Service exports & 2,719 & 3,154 & 3,659 & 4,244 & 4,923 \\
\hline Net interest payments & $-4,186$ & $-5,027$ & $-5,655$ & $-6,362$ & $-7,158$ \\
\hline \multicolumn{6}{|l|}{$\begin{array}{l}\text { Service imports less net } \\
\text { interest plus unilateral } \\
\text { transfers }\end{array}$} \\
\hline \multicolumn{6}{|l|}{ Net direct foreign } \\
\hline investment & 2,212 & 2,566 & 2,976 & 3,453 & 4,005 \\
\hline Net borrowing & 5,315 & 5,027 & 5,655 & 6,362 & 7,158 \\
\hline Merchandise imports ${ }^{b}$ & $-18,084$ & $-16,319$ & $-18,930$ & $-21,960$ & $-25,474$ \\
\hline \multicolumn{6}{|l|}{ Addenda } \\
\hline Current account balance & $-10,742$ & $-7,593$ & $-8,631$ & $-9,815$ & $-11,163$ \\
\hline Trade balance & $-2,840$ & 1,745 & 2,024 & 2,347 & 2,722 \\
\hline Net debt at end of period & 40,215 & 45,242 & 50,897 & 57,259 & 64,417 \\
\hline \multicolumn{6}{|l|}{ Merchandise imports in 1979} \\
\hline prices & $-18,084$ & $-13,055$ & $-13,767$ & $-14,519$ & $-15,311$ \\
\hline
\end{tabular}

Sources: Banco Central do Brasil, Relatório 1982 (Brasilia: Departmento Econômico do Banco Central do Brasil, 1983), and Boletim Mensal, vol. 19 (March 1983); and author's projections as described in the text.

a. Negative signs indicate debit entries in the balance of payments.

b. Values are f.o.b.

What real GDP growth could have been expected by the prudent planner, given the gloomy projections for imports? The estimation of import functions in Brazil is rendered especially difficult by quantitative restrictions and lack of data. Following the careful work of Eduardo Modiano, however, one can suppose an income elasticity in the demand for all imports of between 1.0 and 1.2 , and a price-elasticity of demand of -0.2 for oil and wheat imports and -1.2 for other imports. ${ }^{5}$ During 1979 petroleum and wheat represented about 40 percent of total Brazilian imports. As a first approximation, then, a real devaluation of 20 percent would have been necessary to reduce imports by 16 percent while holding output constant. A full pass-through, including oil, would have been

six months, paying cash, even if gross trade credits went to zero. The reserve-debt ratio has been found to be an important influence on spreads charged to borrowers in the international financial markets, at least in some studies analyzing the years before 1982 .

5. Eduardo M. Modiano, "Consequencias Macroeconômicas da Restriçao Externa de 1983: Simulaçoes com un Modelo Econometrico para a Econômia Brasileira" (Pontificia Universidade Catolica do Rio de Janeiro, May 1983). 
necessary, and absorption would have had to be cut relative to output. In addition, the real income loss due to the worsening of the external terms of trade would have been unavoidable; that loss has been estimated at around 1 percent of GNP. A real devaluation of at least 20 percent for 1980-82 relative to 1977-79 would have allowed for greater export growth or a reduction in export subsidies; those subsidies received increasing criticism from the United States.

\section{Reality versus the Counterfactual Projections}

The counterfactual projections can be compared with what actually occurred during 1980-82. As the projections implied a zero overall balance-of-payments surplus, deviations between reality and the counterfactual projections ("surprises" for short) may be stated as either contributing to a balance-of-payments surplus or deficit. Thus if a debit item such as imports was larger in reality than in the counterfactual projections, it would have been recorded as a surprise with a negative sign. These deviations are presented in table 2 .

During 1980 and 1981 recorded merchandise exports expanded beyond the prudent planner's expectations, but took a sharp turn for the worse during 1982, falling below the planner's parsimonious forecast. Table 3 shows trends in the geographic destination of Brazilian exports during the 1970s and early 1980s. A diversification away from exports to industrial countries had been occurring since the late 1960s and accelerated during 1980-81. During 1977 through 1979, industrial countries accounted for 64 percent of Brazilian exports; during 1980-82 that share fell to 57 percent. This trend was contemplated with satisfaction, especially because it was accompanied by a diversification away from traditional exports of primary products. Yet during 1982 the new markets accounted for most of the decline in exports, as can be seen in table 3: exports to industrial countries fell by about 4 percent between 1981 and 1982 , accounting for only 16 percent in the decline of Brazilian exports. Exports to Japan, Italy, the United States, and France actually expanded (modestly) between 1981 and 1982, in nominal terms.

With the wisdom of hindsight, it is now evident that pre-1982 conditions in the international financial markets influenced the Brazilian balance of payments directly, by means of capital inflows, but also 
Table 2. Reality versus the Counterfactual Projections: "Surprises" and Their Effects on Balance-of-Payments Surplus or Deficits, 1980-82

Million of dollars

\begin{tabular}{|c|c|c|c|}
\hline Item & 1980 & 1981 & 1982 \\
\hline Merchandise exports ${ }^{b}$ & $+2,068$ & $+2,339$ & $-4,132$ \\
\hline Service exports & -10 & -12 & -911 \\
\hline Net interest payments & $-1,284$ & $-3,506$ & $-4,995$ \\
\hline $\begin{array}{l}\text { Service imports less net interest plus } \\
\text { unilateral transfers }\end{array}$ & +648 & $+1,237$ & $+1,011$ \\
\hline Net direct foreign investment & $-1,034$ & -650 & -911 \\
\hline Net borrowing & $+2,776$ & $+4,378$ & $-1,581$ \\
\hline Merchandise imports ${ }^{\mathrm{b}}$ & $-6,636$ & $-3,161$ & $+2,563$ \\
\hline Balance-of-payments deficit (surplus) & 3,472 & $(625)$ & 8,956 \\
\hline \multicolumn{4}{|l|}{ Addenda } \\
\hline Estimated net debt at end of period ${ }^{c}$ & 51,490 & 60,898 & 74,635 \\
\hline Actual current account balance & $-12,807$ & $-11,734$ & $-16,279$ \\
\hline Actual trade balance & $-2,823$ & $+1,202$ & +778 \\
\hline $\begin{array}{l}\text { Actual merchandise imports in } 1979 \\
\text { prices }\end{array}$ & $-17,920$ & $-15,535$ & $-14,189$ \\
\hline
\end{tabular}

Sources: Relatório 1982; Boletim Mensal; and table 1.

a. Actual less counterfactual. Contributions to balance-of-payments surplus (deficits) are indicated by a plus (minus) sign.

b. Values are f.o.b.

c. Estimated by adding net borrowing and the balance-of-payments deficit (reduction in net international reserves) to the net debt outstanding in the preceding year. For 1979 the net debt used corresponds to the official estimate by the Banco Central do Brasil for debt with maturity of more than one year.

indirectly, by the financing of Brazilian merchandise exports. Argentina, Chile, and Poland purchased Brazilian goods, in part drawing on external loans; in turn, Brazil provided credit for an increasing share of its manufactured goods during 1980-82. As export subsidies were reduced after 1978, export credits were increasingly used as an offset; during 1980-82 gross export credits accounted for about 20 percent of manufactured exports, according to the Banco Central do Brasil. These trends are behind stories from late 1982 alleging that a nontrivial share of the reported Brazilian international reserves was made up of short-term Polish IOUs.

Table 4 suggests that the seizing up of international financial markets during 1982 had a more direct impact on Brazilian exports than either the weakness of oil prices or the depression (or protectionism) of the industrial countries. But of course the problems in financial markets would be difficult to explain without the post-1979 macroeconomic trends in industrial countries, and it remains true that Brazilian 1982 
Table 3. Growth Rates and Absolute Changes in Brazilian Merchandise Exports, Selected Periods, 1971-82

\begin{tabular}{lccccc}
\hline & \multicolumn{3}{c}{$\begin{array}{c}\text { Annual growth rates } \\
\text { (percent) }\end{array}$} & & \\
\cline { 2 - 3 } \multicolumn{1}{c}{ Item } & $\begin{array}{c}1971-73 \\
\text { to }\end{array}$ & $\begin{array}{c}1977-79 \\
\text { to }\end{array}$ & & $\begin{array}{c}\text { Absolute changes } \\
\text { (millions of dollars) }\end{array}$ \\
\cline { 5 - 6 } \cline { 5 - 6 } & $1977-79$ & $1980-82$ & & $1979-81$ & $1981-82$ \\
\hline All merchandise exports & 20.5 & 16.7 & 8,049 & $-3,118$ \\
Industrial countries & 18.0 & 12.3 & & 3,169 & -510 \\
Latin America & 27.5 & 23.0 & & 1,744 & $-1,407$ \\
Middle East & 29.1 & 42.5 & 732 & -46 \\
Comecon & 24.7 & 17.6 & 723 & -536 \\
Rest of world & 24.2 & 22.5 & & 1,681 & -619 \\
\hline
\end{tabular}

Sources: Same as table 2.

a. Geographic groups are similar but not identical to those found in publications of international organizations. Industrial countries are Canada, Spain, the United States, the European Free Trade Association, the European Economic Community, Australia, and Japan. Values are f.o.b.

b. The Soviet Union and the other countries that comprise the Council for Mutual Economic Assistance.

Table 4. Reality versus the Counterfactual Projections: Price Indexes for Brazilian Imports and Exports, 1980-82

Index $(1979=100)$

\begin{tabular}{lrrr}
\hline \multicolumn{1}{c}{ Index } & 1980 & 1981 & 1982 \\
\hline Average export dollar prices & & & \\
Counterfactual & 112.5 & 123.8 & 136.1 \\
Actual & 105.9 & 100.0 & 94.1 \\
Average import dollar prices & & & \\
Counterfactual & 125.0 & 137.5 & 151.3 \\
Actual & 128.1 & 142.2 & 136.7 \\
Terms of trade & & & \\
Counterfactual & 90 & 90 & 90 \\
Actual & 82 & 70 & 68 \\
\hline
\end{tabular}

Sources: Relatório 1982; and author's projections as described in the text.

a. Terms-of-trade data were rounded so as to follow the published index $(1977=100)$.

exports fell substantially below what a prudent planner could have expected in 1979. As shown in table 4, the export shortfall was due to an unexpected weakness in export dollar prices; indeed, even after declining during 1982, the export volume for that year was almost one-third above the 1979 level, yielding an average annual growth rate of almost 10 percent. ${ }^{6}$ Note also that the 1982 terms of trade were 32 percent below those for 1979; three-year averages for 1977-79 and for 1980-82 show a

6. Volume and price data are not available by geographic destination of exports. 
terms-of-trade decline of 34 percent, comparable to the performance during the early 1930 s. $^{7}$

The geographic data do warn that economic recovery in the industrial countries may have a disappointing impact on Brazilian exports unless the new Brazilian markets outside the industrial nations manage to regain some of their previous dynamism. At best, the lag between OECD recovery and Brazilian export expansion is likely to be longer than in previous cycles. Projected exports of $\$ 22$ billion for 1983 are still below what the prudent planner expected for 1982. A more obvious lesson of tables 3 and 4 is that greater attention to geographic and product composition of exports is necessary when analyzing creditworthiness; this is done for centrally planned economies (where "hard currency" earnings are separated from the rest), and it may be called for when analyzing semi-industrial countries.

The 1980-81 export expansion cannot be said to have received encouragement from exchange rate policy. A careful calculation by Nogueira Batista of the real exchange rate for the Brazilian cruzeiro visà-vis the dollar, $A$, and vis-à-vis a basket of currencies of industrial countries, $B$, yields the following average yearly results, with indexes set at $1979=100:^{8}$

\begin{tabular}{rrr} 
& \multicolumn{1}{c}{$A$} & $B$ \\
1980 & 102.5 & 99.8 \\
1981 & 93.2 & 80.5 \\
1982 & 94.1 & 77.0
\end{tabular}

The overvaluation trend in the effective real exchange rate for $B$ would have been more marked for 1982 if the sharp devaluations in the currencies of neighboring trading partners, such as Argentina, Chile, Mexico, and Uruguay, had been taken into account. In the early $1980 \mathrm{~s}$ Brazilian overvaluation was more gradual than that of its neighbors, but it was not reversed as quickly.

Net borrowing of more than the counterfactual projections made a

7. Between 1928-29 and 1932-33 the Brazilian terms of trade deteriorated by 38 percent. See Carlos F. Diaz-Alejandro, "Latin America in Depression, 1929-39," in Mark Gersovitz and others, eds., The Theory and Experience of Economic Development: Essays in Honor of Sir W. Arthur Lewis (London: Allen and Unwin, 1982), p. 335.

8. Paulo Nogueira Batista, Jr., Mito e Realidade na Dívida Externa Brasileira (Rio de Janeiro: Editora Paz e Terra, 1983), chap. 2.1, tables 1 and 2. 
bigger contribution to the balance-of-payments surplus during 1980 and 1981 than unusual exports did. Given serious charges of "creative accounting," especially since 1979, the boundaries between autonomous and induced, between voluntary and involuntary, as well as between short- and long-term capital movements appear especially blurry for the early 1980s. Therefore, when considering borrowing deviations from the counterfactual projections, it seems better to combine net borrowing with the balance-of-payments deficit. This procedure yields surprise additional net borrowing of $\$ 6.25$ billion in 1980 , $\$ 3.75$ billion in 1981 , and $\$ 7.38$ billion in 1982 . By adding these numbers to the borrowing projected in table 1 and to net debt at the end of 1979, one obtains the estimates for net debt found at the bottom of table 2, which excludes the short-term debt existing at the end of 1979. Calculated in this fashion, net debt grew at an annual rate of 23.1 percent between the end of 1979 and the end of 1981, and by an additional 22.6 percent during 1982 .

The supply of external funds during 1980 and 1981 was mostly voluntary; the same cannot be said for the net borrowing during 1982 . Contrary to the cases of Argentina, Chile, Mexico, and Uruguay, capital movements by private Brazilian residents probably had a relatively small impact on the figures discussed in this paragraph. The fairly tight Brazilian exchange controls allow a safety valve in the form of black markets, generally tolerated, for dollars and gold. The 1982-83 crisis was reflected in the short run more in the spread between the black market and the official cruzeiro than in uncontrolled private flows influencing net official and officially guaranteed debt. During 1983 even the old Chilean as well as the new Mexican governments have retained some form of exchange controls and multiple exchange rates.

The third favorable (although minor) balance-of-payments surprise shown in table 2 involves a heterogeneous category of net service imports, including profit remittances, which grew at less than the assumed 16 percent a year. Between 1971-73 and 1977-79 this debit item grew at an annual rate of 19.5 percent; between 1977-79 and 1980-82 it grew at 12.8 percent a year. Possible explanations include a tightening of exchange controls, the sharply depreciating black market for the cruzeiro, and the 1981-82 recession.

So much for the (rather ambiguous) good news for the Brazilian balance of payments during 1980-82. The notoriously bad news was the higher-than-expected interest payments, the burden of which has grown 
and continues to grow. Comparing actual net interest payments by Brazil with the net debt estimated in table 2 for the end of the previous year, one obtains the implicit interest rates shown in column A below; the implicit rates derived by comparing actual net interest payments with an estimate of the contemporaneous midyear net debt (calculated as a simple average of end-of-the-year debts) are also shown in column B for the sake of comparison:

$\begin{array}{ccc} & A & B \\ 1979 & 13.2 & 11.7 \\ 1980 & 15.7 & 13.8 \\ 1981 & 17.8 & 16.3 \\ 1982 & 18.7 & 16.8\end{array}$

Using the more realistic rates in column A, one can decompose the surprises in net interest payments shown in table 2 into three parts: those arising from higher-than-expected interest rates, given the counterfactual debt, $\Delta r \cdot D$; those arising from higher-than-expected debt, given counterfactual interest rates, $\Delta D \cdot r$; plus a term showing the interaction between surprises in debt and in interest rates, $\Delta D \cdot \Delta r$. The (rounded) results of such decompositions for 1980-82 are as follows, in billions of current dollars:

$\begin{array}{lcccc} & \Delta r \cdot D & \Delta D \cdot r & \Delta D \cdot \Delta r & \text { Total } \\ 1980 & 1.3 & 0.0 & 0.0 & 1.3 \\ 1981 & 2.4 & 0.8 & 0.3 & 3.5 \\ 1982 & 3.2 & 1.3 & 0.6 & 5.0 \\ \text { Total } & 6.8 & 2.0 & 1.0 & 9.8\end{array}$

By 1982 higher-than-expected interest rates still accounted for at least 64 percent of the surprise in interest payments.

Data on both the stock and the inflow of direct foreign investment in Brazil show a slowdown during the early 1980s relative to the 1970 s. Between 1971-73 and 1977-79 the net inflow of direct foreign investment grew at 17 percent a year, according to balance-of-payments statistics; the corresponding figure is only 3 percent a year when the inflows for 1980-82 are compared with those of the previous three years. Was the slowdown due to a sudden tightening of Brazilian regulations under the "nationalist" Delfim Netto? There is little evidence favoring this hypothesis. A much simpler and more plausible explanation blames deterio- 
rating profit expectations due to adverse macroeconomic conditions, both inside and outside Brazil. After all, private fixed capital formation has not shown much expansion under the Reagan and Thatcher governments, either, while recent experiences in Chile and Jamaica show that favorable incentives will not attract much direct foreign investment when macroeconomic conditions are unfavorable. It may also be noted that in 1982 the book value of the stock of U.S. foreign direct investment declined for the first time since $1946 .{ }^{9}$

In 1980 the Brazilian real GDP, which grew during the previous three years at an annual rate of about 5.7 percent, expanded almost 8 percent, boosted partly by favorable weather. Industrial output, which had been expanding at 5.5 percent a year in 1977-79, grew at 7.9 percent during 1980, while agriculture grew at 6.3 percent. Remarkably, the import volume was held at 1979 levels, and import dollar prices rose only slightly more than the 25 percent that the prudent planner expected. That combination, of course, yielded an import bill that exceeded the counterfactual one by $\$ 6.6$ billion. By the second half of 1980 even the sanguine minister of planning of Brazil recognized that balance-ofpayments conditions and signals from foreign bankers suggested the need for less expansionary monetary policies, as well as other measures. Erratic and contradictory policy announcements continued, chronicled and analyzed by Arida, Bacha, Bacha and Malan, and Lopes and Modiano. ${ }^{10}$ The tightening of monetary policy came after a large expansion of subsidized credit to agriculture in late 1979 and 1980 , an inept combination of a large devaluation in late 1979 and the unrealistic presetting of the pace of devaluation and of interest rates for 1980 , at a time when the consequences of the new wage law of late 1979 gave an upward

9. “U.S. Investments in Foreign Entities Fell 2.2\% in 1982," The Wall Street Journal, August 24, 1983.

10. See Persio Arida, Divida Externa, Recessao e Ajuste Estrutural: O Brasil Diante da Crise (Rio de Janeiro: Editora Paz e Terra, 1982); Edmar L. Bacha, "Vicissitudes of Recent Stabilization Attempts in Brazil and the IMF Alternative," in John Williamson, ed., IMF Conditionality (Washington, D.C.: Institute for International Economics, 1983), pp. 323-40; "The IMF and Prospects for Adjustment in Brazil,"' in John Williamson, ed., Prospects for Adjustment in Argentina, Brazil, and Mexico: Responding to the Debt Crisis (Washington, D.C.: Institute for International Economics, June 1983), pp. 31-42; Edmar L. Bacha and Pedro Malan, "Brazil's Debt: From the Miracle to the Fund" (Pontificia Universidade Catolica do Rio de Janeiro, 1983); and Francisco L. Lopes and Eduardo M. Modiano, "Indexaçao, Choque Externo e Nível de Atividade: Notas Sobre o Caso Brasileiro," Pesquisa e Planejamento Econômico, vol. 13 (April 1983), pp. 69-90. 
nudge to inflation. The second oil shock added to cost-push pressures; this time it was passed on to domestic prices to a greater extent than after the first oil shock. As a consequence of the monetary tightening, real GDP declined during 1981 by 1.9 percent, and grew by only 1.4 percent during 1982, according to publications of the Banco Central do Brasil. The import volume fell by 14 percent in 1981 and by a further 9 percent in 1982. As may be seen in table 2, during 1982 actual imports were running below the austere counterfactual estimates. Comparing the three-year averages for 1977-79 and 1980-82, one obtains an actual decline in the import volume of 5 percent, compared with a corresponding counterfactual cutback of 18 percent. For 1983, imports are projected at $\$ 16$ billion, or below 1979 imports in nominal terms, and 17.5 percent below the 1982 imports at current prices. The fall in imports of machinery and equipment appears to have been particularly severe.

A number of major points are apparent in this counterfactual exercise. Brazilian authorities followed a risky growth strategy for 1980, which was very debatable even ex ante. By 1981, however, they were on the way to correcting the 1980 mistake, albeit in a half-hearted fashion (for example, the real exchange rate was moving in an opposite direction from the desirable trend, partly due to unexpected dollar appreciation vis-à-vis other major currencies, but also due to inconsistent domestic policies). By 1982, international economic conditions were such that even prudent planners would have been in serious trouble if they had stuck to their 1979 expectations and policies. Exports fell $\$ 4.1$ billion below their target, and excess interest payments on their planned debt were $\$ 3.2$ billion. Covering these $\$ 7.3$ billion worth of unpleasant 1982 surprises, especially after the Malvinas (Falkland) Islands war and the "Mexican August," could have been difficult, even for a Brazilian Volcker. Data for 1983 are likely to confirm that no plausible prudence during 1980-81 could have sheltered Brazil from the consequences of the violent, real and financial, external shocks of 1982-83.

\section{Special Characteristics of Brazilian Macroeconomics}

The celebrated Brazilian indexation schemes were not well suited to handle the required post-1973 adjustments in domestic relative output and factor prices. Changes in wage policy since 1979 have made the 
inflationary impact of relative price corrections greater than before that year, and this has made public officials even more timid (or erratic) in adjusting exchange rates, oil prices, and prices of other crucial items. Nevertheless, those attempts to change relative prices, coupled with monetary and fiscal policies that remained fairly permissive until late 1980 , led to an acceleration of inflation. The annual average rate of inflation from 1970 to 1973 was kept below 20 percent, with a little help from index manipulation. From 1973 to 1979 the annual rate rose to 39 percent, jumping to 100 percent on average from 1979 to 1982 . The inflation rate will exceed 140 percent in 1983. Brazilians, who had become masters at living with inflation and growing with it, began to worry that the price level could zoom upward at the slightest change in relative prices; money, narrowly defined as noninterest-earning financial assets, has become a very small proportion of financial wealth, which includes many money substitutes.

Government technocrats had expected 1982 to be a year of recovery; after the 1981 correction, they hoped for a 5 percent real GDP growth. Starting with the outbreak of the Malvinas (Falkland) war in April, it became clear that fresh external shocks made that target unrealistic. The major shock, as noted earlier, was the "Great Fear" in international financial markets, which hit important Brazilian customers first and by September hit Brazil directly. The real shock involved in the post-1979 worsening of the terms of trade, interest rates included, began to look more serious and permanent during 1982 than originally thought. With the first reasonably open elections in many years scheduled for November, the government appeared to wait for some deus ex machina and insisted that "Brazil is different," a thought echoed abroad during September and October, even as Brazilian officials engaged in fanciful financial manipulations to avoid a pre-election crisis. By the end of 1982 the unthinkable had happened: Brazil was ready to sign a standby agreement with the International Monetary Fund, to be discussed below.

If backward-looking indexing was not well suited to accommodate relative price changes, the post-1964 authoritarian style of economic policymaking was even less suited to seek consensus on how to share the burden of adjustment to post-1979 terms of trade and other circumstances, and this could not be blamed on previous governments. Adding to the difficulties of finding an economic policy with a minimum of support were the opposition's fears of jeopardizing the fragile process 
of democratization. Erratic policy changes also contributed to the collapse of the credibility of government economists, even among conservative groups, both Brazilian and foreign.

The political quagmire has hidden a substantial private consensus in Brazil on the diagnosis and broad remedies for the crisis. Foreign exchange shortages are viewed as the major constraint on Brazilian growth; contrary to the views of this problem held during the 1950s, now shocks to the capital account are thought to be as important as those in the current account. Although real income (not product) losses arising from a permanent deterioration of the terms of trade (at most, 4 percent of GNP) cannot be recouped, and although some reallocation costs may also be inevitable, most observers within Brazil emphasize the avoidance of "secondary" adjustment costs, which would cut output without bringing significant gains to the balance of payments. Widespread bankruptcies induced by extravagant real domestic interest rates and recession, for example, which destroy many years of "learning by doing," are viewed as a secondary burden, a hardship not really necessary to cope with the balance-of-payments crisis. On the other hand, even opposition economists, if pressed, will concede the need to reduce real wages in terms of tradable goods-that is, to raise the exchange rate relative to money wages. The 1979 wage law appears to have been effective in maintaining average real wages at about 1977-79 levels during 1980-82, while decreasing the spread around that average real wage.

Fragmentary data on imports of machinery and equipment and on domestic production of capital goods suggest a sharp decline in investment during 1981-83. Because of the nature of national accounting, these events will eventually be registered also as a contraction of domestic saving. Analysts fond of ex post identities may rush to argue that a lack of incentives to save, rather than foreign exchange difficulties, are behind the Brazilian crisis. Yet an autonomous and nonselective increase in private or public saving under present circumstances is unlikely by itself to bring much relief to the balance of payments; instead it might lead mainly to a further decline in output. Two-gap analysis is alive and well in Brazil (as convincingly argued by Bacha). ${ }^{11}$ Because of an acute short-

11. "Growth with Limited Supplies of Foreign Exchange: A Reappraisal of the Two Gap Model,', in M. Syrquin, L. Taylor, and L. Westphal, eds., Economic Structure and Performance: Essays in Honor of Hollis Chenery (Academic Press, forthcoming). 
run complementarity between domestic and imported inputs (including oil), rigid debt-service commitments, and internal and external limits on the quick expansion of foreign exchange earnings, an economy in which the sum of imports and exports amount to about 20 percent of GNP and in which there are substantial actual and potential domestic resources has become dependent for its short-term performance on the few additional billion dollars that may be wrangled from fitful foreign bankers.

What about the public deficit, passive monetary policy, and accelerating inflation? Consensus on these areas is shakier, but an informed view common within Brazil is that a weak link exists between budget deficits, on the one hand, and the balance of payments and inflation, on the other. The dynamics of inflation are viewed as being dominated in the short-run by backward-looking indexing rules while only a minority regards excess demand as the major source of either internal or external imbalance since 1981. ${ }^{12}$ There is considerable concern, and not just among entrepreneurs in the private sector, about the size and flabbiness of the public sector, whose enterprises account for a good share of fixed capital formation. The opaqueness of the labyrinthian public sector budget is regarded as a national disgrace, the product of an authoritarian state that need not render clean accounts. A promiscuous intermingling of the budget for public enterprises, the accounts of the monetary authority, and the budgets for the federal, state, and local governments makes clear and up-to-date knowledge of public finances nearly impossible. Massive subsidies to agricultural producers (not exactly the poorest of the poor), for example, appear in the monetary budget. Different approaches to inflationary accounting make the measurement of the budget deficits even more confusing, as is seen below. If balanceof-payments pressures were to disappear overnight, and if indexing rules were revised to break the inflationary spiral, a fresh look at the Brazilian public sector would remain a high priority for a government committed to fair and efficient growth, while a cleaner separation of fiscal and monetary policy would seem like a necessary first step for rational macroeconomic policymaking. But neither a sudden tightening of monetary policy nor an across-the-board slashing of public investment will

12. Francisco L. Lopes and Edmar L. Bacha, "Inflation, Growth, and Wage Policy: A Brazilian Perspective,' Journal of Development Economics, vol. 13 (August-October 1983), pp. 1-20. 
necessarily move toward achieving the desired medium-term reforms in the public sector.

The balance-of-payments crisis in the early 1980s and its impact on public finances has given new relevance to other old-fashioned fiscal policy points. Much of the Brazilian public expenditures is indexed, not just to the general price level, but to the exchange rate. Servicing the foreign debt is an obvious example. Shocks calling for a change in the real exchange rate will affect the budget unless the public sector is in some sense hedged against such an event-for example, by having a portion of tax revenues tied to tradable-goods prices or to profits in the tradable-goods sector. Without such hedging in the revenue base, temptation will grow to use multiple exchange rates as a fiscal rather than a balance-of-payments tool.

In short, the opinion is widespread in Brazil that handling the crisis needs to go beyond calls for "gradualism" and an "incomes policy," phrases that mean many things to different people and are even invoked to praise post-1964 authoritarian policies. Adjusting in the short- and medium-term to the external circumstances of the 1980s while maintaining growth and controlling inflation is likely to involve either a genuine democratic opening, with broad political support needed to make painful adjustment measures work, or a sharp return to an authoritarian system. The difficult task of seeking both economic and political solutions to the crisis is made more explosive by the presence of foreign actors who have a classic role that does not call for political subtlety and who are perceived with hostility by influential segments of Brazilian public opinion. The entire matter has been well summarized by a perceptive observer of many scenes: ${ }^{13}$

Financial discipline and reasonably efficient markets are quite desirable, even indispensable, in the medium term. But that does not mean, of necessity, that the transition should take a form hostile to society and progress. We therefore have to look to ways of shaping a broad social consensus supportive of stabilization. But this means, of course, that incomes policy is the cornerstone of effective, socially acceptable conditionality. Effective stabilization is, above all, not a technical issue but a political one.

Before turning to Brazilian relations with foreign banks and the

13. Rudiger Dornbusch, "Comments," in John Williamson, ed., IMF Conditionality, p. 229. 
International Monetary Fund, one may note that the macroeconomic disturbances of the early 1980s should not obscure the long-term case for capital inflows into Brazil, although granting that both the financial instruments and the projects that led to those inflows during the last twenty years or so leave much to be desired. Unless the adjustment of the 1980s is mismanaged, or the international economy fails to recover, both of which would turn export-oriented Brazilian projects into useless scrap, it is still likely that future economic historians will view the capital inflows of the 1970s, with all their imperfections, as having been beneficial from the standpoint of a plausible Brazilian welfare function. The high Brazilian debt-export ratio, in other words, is compatible with investment plans in which the social rate of return has exceeded borrowing costs including risk premiums; similar debt-export or debt-GNP ratios were characteristic of dynamic capital-importing nations such as Australia, Argentina, and Canada before World War I. Detailed microeconomic studies do not exist to document this conjecture, but even at the peak of criticisms of bankers and borrowers during 1982-83, few examples have been given for Brazil (in contrast to Argentina and Chile) of 1920s-type ex ante foolish investment projects financed by debt.

\section{Dealing with Foreign Banks and the IMF}

As already mentioned, during August and September of 1982 Brazil was still given high marks for its debt management: Brazil was not Mexico. (Less than a year later the same phrase was repeated, but with a different meaning.) Partly deluded by their carefully nurtured reputation of technocratic wizardry, Brazilian authorities rejected any suggestion of significant rescheduling of the external debt, even after August 1982. Opposition proposals along those lines were ridiculed as showing the naiveté, irresponsibility, and irrationality of its economists and politicians. Some observers may argue that Brazilian authorities either underestimated the length of the crisis in international lending or expected a very special and lenient treatment from banks, the IMF, and the U.S. government, attitudes that ex ante were not as implausible as they may now appear. Rather than a realistic multiyear rescheduling plan, during late 1982 and early 1983 Brazil and its foreign bankers put together their ill-fated "four projects," which at their conception were 
regarded by independent observers as insufficient to cover 1983 financing needs, even if all targets had been reached. ${ }^{14}$ The fourth of these projects, which called for a reestablishing of short-term deposits in Brazilian banks abroad that had been withdrawn during 1982, is now generally regarded as singularly inept; it has raised doubts about the financial competence not only of Brazilian technocrats, but also of the foreign bankers who designed the package. Brazilian technocrats apparently expected too much from customer relationships with several favored New York banks and thus helped to create frictions among U.S. banks, large and small, and between U.S. banks and banks elsewhere. The committee of banks advising Brazil has undergone substantial changes and stresses during its first year.

Throughout 1983 Brazil has gone deeper into arrears, while Brazilian banks abroad have become early victims of the failure of the fourth project and the decline of interbank deposits. A little-noticed consequence of the international financial crisis of 1982-83 has been the blow suffered by incipient transnational banks from the third world, such as those of Argentina, Brazil, and Mexico. Trends toward cartelization of private international lending have been strengthened by the collapse of the newcomers, whose international activities had expanded rapidly over the past few years.

Brazilian bargaining power during 1982-83 was considerably weakened by the low level of liquid international reserves (that is, leaving aside Polish and Mexican IOUs). This is just another way of putting the point made above regarding the pretense of treating Brazil as if it was different, and using every available expedient to avoid a clean and significant rescheduling. The contrast here is not merely with Mexico, but with Argentina, which gave up assuming that debt could be serviced according to pre-1982 expectations while its international reserves were still substantial enough to weather possible credit blockades at least for a few months. Brazilian international reserves remain very low, and any serious rescheduling and stabilization plans should include provisions for their replenishment.

Unhappy experiences with the IMF during the late 1950s, plus special relationships with the U.S. government since 1964 and with international

14. For the details of these projects see Edmar L. Bacha, "The IMF and the Prospects for Adjustment in Brazil." 
banks during the 1970s, led the Brazilian government to keep the IMF at arm's length until the last quarter of 1982. As late as mid-1982 suggestions (typically by foreigners) that Brazil either should or would go to the IMF were dismissed by most Brazilians, regardless of political views. Indeed, the 1981 austerity was partly sold to domestic audiences because it would make a trip to the IMF unnecessary.

The program negotiated between Brazil and the IMF during late 1982 and early 1983 is now widely considered to be as unrealistic as the four projects negotiated with foreign private banks, especially after the February 1983 devaluation. ${ }^{15}$ The major problem was the very stringent fiscal performance criteria, set in nominal terms, combined with an underestimation of inflation. Bacha calculates that observance of the fiscal performance criteria would have led to a decline in Brazilian real GDP by over 15 percent in 1983. By May it was obvious that the internal part of the program was not being fulfilled, and the IMF suspended disbursement of its credits to Brazil. A new painful round of negotiations among the private banks, the Brazilian government, and the IMF began in June 1983. Baffled Brazilians watched the comings and goings of economists from the IMF and the banks and often heard news about the Brazilian economy from the junior staff of those institutions. Nationalist irritation at the "bananization" of the Brazilian republic became a more potent source of elite discontent than growing unemployment and decline in real income. These unhappy trends occurred despite the tact and discretion displayed by the new IMF team that visited Brazil in June.

By late September 1983 a new letter of intent had been agreed upon by the Brazilian government and the IMF. According to incomplete press reports, the new agreement called for ambitious targets for 1984: the virtual elimination of the public sector deficit, somehow adjusted for inflation; an inflation of 55 percent by the end of that year, with corresponding monetary and credit targets; a revision of the wageindexation formulas; and a trade surplus of $\$ 9$ billion. These targets allegedly led to the resignation during early September of the president of the Banco Central do Brasil, Carlos Langoni, who is said to have found the targets unrealistic. Performance criteria for the public sector deficit for the rest of 1983, on the other hand, seemed lax relative to

15. Ibid.; and Rudiger Dornbusch, "Discussion," in John Williamson, ed., Prospects for Adjustment in Argentina, Brazil and Mexico, pp. 43-50. 
earlier letters of intent, and the original inflation targets for 1983 were abandoned.

An earnest effort to meet the 1984 targets will involve a significant cut in public real aggregate demand; unless an implausible "crowding in" occurs, recovery from the Brazilian depression of the early 1980s will be weak or nonexistent. Domestic opposition to the new letter of intent and associated policies has been intense: during October 1983 the revitalized Brazilian Congress defeated a decree law restricting salary increases for the next two years to 20 percent below the cost-of-living increase. At this writing, it remains moot whether political circumstances will permit desirable changes in relative prices, particularly the ratio of nominal wages to the exchange rate, in a context of neither explosive inflation nor a further cut in output. What began in September 1982 as a serious economic problem for Brazil had become a year later a profound political and institutional crisis, threatening not only that country, but also the credibility of a beleaguered IMF.

Besides traditional debates over stabilization policies, recent Brazilian discussions with foreign creditors have highlighted three issues. The first is the previously mentioned controversy over the proper measurement of the public sector deficit, and over the link between that deficit, somehow measured, and inflation and the balance of payments. ${ }^{16}$ As a result of changes in the price level and the exchange rate, the public sector may experience capital gains and losses on outstanding debt: the change in the real value of the public sector liabilities would be the proper measure of the deficit; this measure is shunned by the IMF, which prefers to use the looser concept of "public sector borrowing requirements." The latter measure could be positive, due to nominal amortizations, while the former measure yields a budget surplus. The issue remains an accounting one unless either measure is related to notions about how the economy operates; specifically, the measures have to be related to aggregate demand, inflation dynamics, and the behavioral patterns in financial markets. Accounting nevertheless remains important because it influences the aspects of the policy debate that get the greatest public attention; claiming that the Brazilian budget deficit is 16 percent of GNP is more than twice as stunning as saying it is 8 percent of GNP, a figure which, after all, is not so different from the corresponding

16. Ibid.; and Bacha, "The IMF and the Prospects for Adjustment in Brazil." 
one in the United States. The third 1983 letter of intent apparently uses various definitions for the public sector deficit.

The second issue is what IMF conditionality should focus on. It is now expected that Brazil will meet the foreign trade targets set for 1983 (a trade surplus of $\$ 6$ billion) even as it has failed to meet targets for the budget deficit, credit expansion, and inflation. This fact not only dramatizes the looseness in the link between Brazilian budget deficits and the balance of payments, but also raises the issue of why the IMF should care what the Brazilian inflation and budget deficits are when Brazil is apparently meeting the foreign trade targets agreed upon with that institution. I have argued elsewhere that the appropriate focus of IMF conditionality should be the balance of payments and little else. ${ }^{17}$ This is not because external balance can be neatly partitioned from the internal one, but because an international institution (with membership spanning Romania, France, South Africa, and the United States) cannot with any degree of credibility, given the state of macroeconomics, argue that Brazilian wheat subsidies are more crucial to the chances of getting IMF loans repaid than government-created South African labor market imperfections are. To repeat: this is not to say that one finds the economics (nor the politics) of the Brazilian planning minister more admirable than those of the head of the Western Hemisphere department of the IMF. The suggested focus on the balance of payments emphasizes both the original logic on which IMF conditionality rests and the limitations of current knowledge about the connection between external and internal balance.

The third, and perhaps most crucial, issue raised by the 1982-83 Brazilian negotiations with banks and the IMF is the lamentable state of mechanisms for international debt rescheduling. Banks, the IMF, and governments all seem caught in a clumsy process that no one really regards as the best way to handle unforeseen, unfavorable circumstances; yet no one has yet shown the leadership to put in place or even suggest a more sensible arrangement. Ingenuity and resourcefulness have been shown by several important actors in the international financial game, not the least having been displayed by the Federal Reserve Board of the United States. Although those efforts have avoided financial panic,

17. Carlos F. Diaz-Alejandro, "Comments, " in John Williamson, ed., IMF Conditionality, pp. 341-46. 
they have been insufficient to prevent unnecessary, secondary adjustment costs to Brazil and others and unnecessary threats to international recovery. Since August 1982 the world has lived with international financial markets that are neither free and competitive nor effectively planned; a peculiar semicartelization shakily managed by central banks and the IMF has inflicted on countries like Brazil the costs of monopoly (for example, larger spreads and fees) without some of its benefits (the ability to plan ahead). The short-leash, hand-to-mouth process of handling the Brazilian debt service since August 1982 is offensive not only to Brazilian national pride but also to economic rationality.

The 1982-83 "Great Fear" thrust the IMF into center stage of reschedulings. Despite misgivings about past and present IMF policies and lending practices, it could be argued that, even for Brazil, it was better to have an imperfect IMF at hand than having no IMF at all. Yet it is debatable that a role acceptable in a crisis should become a permanent IMF responsibility. The international equivalent to "bankruptcy judges" found in the United States and other industrial countries remains to be created. The IMF, being itself a lender and borrower, even if in a unique nonprofit fashion, would not be institutionally suited for the role of bankruptcy judge, even if it had plentiful funds to finance what it regards as ideal stabilization plans. An expanded and revitalized IMF plus other multilateral institutions could reduce unexpected debt reschedulings by acting as countercyclical lenders, for example by having a much larger compensatory financing facility. But even under those circumstances problems are likely to remain, calling for a more orderly and impartial debt rescheduling process than the present one.

Throughout history both borrowers and lenders have made mistakes and locked themselves into contracts not suitable for coping with unexpected shocks. During 1982-83, lenders on the whole appear to have even profited from past mistakes, while borrowers bore a disproportionate burden of adjusting to the bad news. The weakness of the rescheduling process, which promises so few fresh funds and so little growing space, together with the perceived imbalance in paying for past errors, provides the temptation for Brazil to break the negotiating impasse and step into the leadership void by suggesting to creditors its own rescheduling plan. Doing so with suitable bargaining bravado would also help to gain local support for austerity measures and policy reforms, and perhaps could also induce neighbors to adhere to Brazilian proposals. 
The $\$ 1.5$ billion loan to Brazil from the Export-Import Bank of the United States during early August 1983 could have been an indication of how close Brazil has come to declaring a unilateral rescheduling plan.

\section{Concluding Observations}

Brazilian real GDP is expected to fall during 1983 by about 3 percent. With a population growth of approximately 2.5 percent a year, the 1983 per capita GDP may be estimated to be about one-tenth smaller than it was in 1980 . The decline since 1980 in real per capita national income is somewhat greater than 10 percent, due to the fall in the terms of trade and the increase in factor payments abroad. Per capita real absorption has been further shaved by the contraction in the current account deficit. While old investments are going partly to waste because of excess capacity and the bankruptcy of existing firms, new investments are postponed or curtailed, hampering future growth. Even optimistically assuming a per capita GDP growth of 3 percent a year starting in 1984, the per capita GDP level of 1980 will be surpassed only in 1987 . The 1981-83 depression is the worst ever recorded in Brazilian national accounts, not excluding that of the early 1930s. Unemployment in 1983, although not accurately measured, appears to contemporaries as a graver problem than it did in 1931. In these circumstances, policies that would further restrain domestic demand are hard to justify and could lead to increasingly serious social disorder if implemented.

Careful projections of the balance of payments of Brazil by William Cline indicate that, given OECD growth of at least 3 percent a year and other plausible conditions, there should be a gradual improvement in standard indicators of Brazilian debt-servicing capabilities. ${ }^{18}$ These projections understandably do not take into account the geographic composition of Brazilian exports and thus may overstate the speed with which OECD recovery will affect Brazilian export expansion. Furthermore, even assuming a modest per capita GDP growth of about 2 percent a year, the Cline projections for Brazil yield a debt-service burden through

18. William R. Cline, International Debt and the Stability of the World Economy, Policy Analyses in International Economics 4 (Washington, D.C.: Institute for International Economics, September 1983). 
1985 that in the past has been associated with rescheduling crises. Note that during 1981-82 the difference between net increments in the Brazilian debt and net interest payments became very small. During the next few years Brazilian current account deficits and a fortiori its net borrowings are likely to be smaller than net interest payments. The appearance of going further into debt simply to meet interest charges that are perceived as extravagant will present political difficulties. Clearly the Brazilian payments situation remains delicate and vulnerable to the whims of nature and to generals and other politicians, both domestic and foreign.

The precise shape of a Brazilian stabilization program that is politically and economically viable can only be decided by Brazilians. However, a foreign economist can point out that a plan that succeeds in moving toward internal and external balance in the context of reviving growth is likely to include the following features:

1. There should be a substantial real depreciation of the exchange rate relative to the 1981-82 levels. Recovery from the depression of the early 1930s involved sharp real depreciations; on this point a repetition of history is warranted. In the near term at least, maintenance of exchange and import controls seems inevitable; the costs of the latter appear greater than those of the former.

2. External debt-service rescheduling that is more drastic than it has been in the past is also called for, and should include a reexamination of spreads and fees, as well as ceilings on the share of foreign exchange earnings that may be absorbed by interest payments in any given year. Rollovers of principal should be extended well into the future, perhaps by creating new debt instruments.

3. Indexation schemes should be revised to exclude price increases arising from supply shocks or deterioration in the external terms of trade, while making the indexation formulas sensitive to expectations about future inflation. As this implies a form of incomes policy, mechanisms to convince workers and public opinion that inflation forecasts will be unbiased, unlike the experience of the late 1960s and early 1970s, would be highly desirable, if not necessary.

4. Budgetary and monetary accounts should be developed and presented in a way that allows a rational discussion of the level and changes in public aggregate demand and financial requirements and permits a 
distinction between cyclical and structural causes of budget deficits. By late 1983 it was very doubtful that the budget deficit was a major cause of either internal or external imbalance. The budget targets for 1984, if achieved, would help only marginally to reach external balance and to lower inflation; those marginal gains would be achieved at severe costs in domestic employment and output. This need to avoid a more depressing fiscal policy in the short run must not obscure the need for a major revision of the social benefit-cost calculus involved in public investments and other expenditures that, after twenty years of authoritarian military government, show signs of serious inefficiencies. Revision of public sector accounts from a long-term perspective could very well lead to a relative reduction of investments in large projects and an expansion in social expenditures, such as those in health and education, plus a more efficient and equitable tax system.

5. A monetary and financial policy is needed that, in the short term, avoids the bankruptcy of sound firms with temporary liquidity problems. Medium-term targets in this area are likely to include a clearer separation of monetary and fiscal policies; the preservation of safe and remunerative financial assets for small and medium savers; and a domestic financial market offering a broader spectrum of private and public instruments, with a wider range of risk and return characteristics.

Before concluding, I note that many questions still remain unanswered about Brazilian performance and policies during the early $1980 \mathrm{~s}$. Ex post it is clear that the timing of the gradual political opening and the correspondingly more liberal wage policy ran into singularly bad luck. Yet those familiar with the remarkable Brazilian policy responses to the external shocks of the early 1930s remain puzzled by the flaccid reaction to the 1982-83 shocks. One can list crucial differences between the international scene and institutional arrangements of the early 1930s and those of the early 1980s; but as late as mid-1982 few observers would have predicted the almost passive and fatalistic Brazilian response to pressures from abroad since August 1982. Perhaps the Brazilian bargaining power was overestimated, or perhaps it could not be used by a regime worn out by almost twenty years of manipulative authoritarianism and technocratic trickery.

It could be argued that the international depression of the early $1980 \mathrm{~s}$ has had a worldwide "disciplining" result that some Argentine econo- 
mists have emphasized as motivation for recessionary stabilization plans in their country. ${ }^{19}$ The uncharacteristic Brazilian gloom of 1983, at any rate, contrasts sharply with the optimism found in the United States regarding the outlook for Latin American debt servicing and international economic recovery.

The buildup of nationalist resentment-some of it reasoned, some not-in Brazil and the rest of Latin America against the visible external actors involved in debt negotiations should not be underestimated. This force could be more explosive than unemployment and declining real incomes in generating unpredictable political changes. Those who would take advantage of present circumstances to press Brazil to alter economic policies that have only a loose link with the 1982-83 payments crisis, such as policies to control trade and foreign investment, are playing with fire. The same warning applies, a fortiori, to attempts to obtain abrupt reversals in Brazilian foreign policies by taking advantage of the weakened Brazilian bargaining position.

Another interesting topic neglected in this paper is the comparison of Brazilian performance not only with that of East Asia, especially South Korea, but also with neighbors like Colombia, whose growth and debt policies during the 1970s were more prudent than those of Brazil. It is not yet clear whether prudence during the 1970s has been rewarded with a sufficiently higher growth during the early 1980s to yield ex post a better long-term record for the cautious.

19. Adolfo Canitrot, Estudios CEDES: Orden Social y Monetarismo, vol. 4, no. 7 (Buenos Aires: Centro de Estudios de Estado y Sociedad, 1983). 


\section{Comments and Discussion}

Richard N. Cooper: I like the basic approach of Diaz-Alejandro's paper, which is to set out a reasonable counterfactual scenario for Brazil since 1979 and to use that as a basis of comparison with actual events. I concentrate my remarks on two features of the paper. In so doing I am slightly more generous both with the Brazilian authorities and with the International Monetary Fund than the author seems to be.

The counterfactual scenario involves projecting forward external receipts and payments on various assumptions about prudent behavior, and deriving allowable imports as a residual from the other projections. Diaz-Alejandro's "prudent planner" would have engaged in an extremely restrictive policy on the basis of this scenario in 1980 and 1981. One of the assumptions on which projections are made is that net external debt should grow at a rate no greater than the interest rate that Brazil faced in international markets, which is estimated by the author at 12.5 percent. There is a vague invocation of growth theory to support this condition.

Such growth in external debt is excessively conservative in a year such as 1979. One point to be made is that Brazil was not on an equilibrium growth path in that year, so rules stemming from growth theory have little relevance. A second and more important point is that 1979 was a year of rapidly escalating oil prices. That development created large new energy-saving investment opportunities in Brazil, along with unexpected obsolescence of part of the existing capital stock. Furthermore, the contractionary impact of higher oil prices would have led to a secondary loss in output, part of which could have been avoided by borrowing (indirectly from OPEC, which was running large surpluses in 1979-80). Thus a Brazilian strategy of borrowing in excess of the interest rate was 
not obviously foolish. As the data in table 2 of the paper show, actual borrowing was substantially in excess of what the author's prudent planners would have allowed; these data support, along with sharply higher exports, a much larger value of imports than his counterfactual scenario would have permitted.

Taken by itself, this seems to me to represent sensible policy. It is complicated in reality by the fact that the Brazilians did not allow domestic oil prices to rise with world prices, so that the investment opportunities and the contractionary effects of an increase in oil prices mentioned above were attenuated. Moreover, the new economic management in late 1979 pledged rather uncritically to grow out of Brazil's evident difficulties through increased government expenditures, partly on enlarged subsidies to the agricultural sector as well as for oil. This strategy is reminiscent of Harold Wilson's unsuccessful attempt to grow out of Britain's balance-of-payments difficulties in 1964, a strategy that hardly inspired confidence. Finally, "improvements" in the scheme of wage indexation were introduced that had the effect of increasing wage indexation in principle to 100 percent of price increases. In practice, on average, indexation turned out in excess of 100 percent of price increases, with much more for workers with low pay. This change in policy, during a period of rapid change in relative prices, would hamstring Brazil's economic policy during subsequent years, as Diaz-Alejandro points out.

The author indulges modestly the widely popular penchant for criticizing the International Monetary Fund (IMF) in its role as economic stabilizer. I have several observations about this role in stabilization programs such as those undertaken by Brazil.

First, successful stabilization programs are still very much an art. Economics as a discipline does not have much to say about the transitional dynamics of moving from one macroeconomic situation to another. Yet these dynamic conditions are often crucial to the success or failure of a stabilization program. Expectations play a major role, as has been lately recognized, but we do not yet have a clear idea of how expectations are formed and how alteration of expectations is influenced by initial conditions. For example, it is possible to imagine circumstances in which a stabilization program characterized by shock treatment will be more successful-that is, less costly in terms of output forgone for a given correction in the balance of payments or a given reduction of the inflation rate-than would a policy of gradualism. It is also possible to imagine circumstances in which the reverse would be true. The presence of the 
IMF in a stabilization program may be helpful in shaping expectations. A stabilization program may be more credible (even if less palatable) to the domestic public as well as to international bankers if it has been endorsed by that institution. Indeed, such endorsement is often necessary these days for any new lending to the country in question. Along with the IMF's own loans, a stabilization program thus permits (but does not require) some gradualism in stabilization. The IMF's contribution to credibility may even outweigh the inevitable technical flaws in the plan it endorses.

Complaints about the IMF, which are endemic in Latin America, are usually misfocused complaints about the situation in which countries find themselves when the IMF is brought in. It is like objecting to the water a fire department sprays on a burning house. Policy analysts should compare choices among feasible alternatives, not between a stabilization program and a nonsustainable past or an idealized future. Edmar Bacha has recently performed an interesting analysis of the Brazilian stabilization program of 1981, which did not involve the IMF. He argues that the program Brazil adopted was at least as harsh as one that would have garnered IMF endorsement, and was more costly insofar as Brazil could have borrowed abroad at somewhat lower cost with an IMF-endorsed program. He reckons the net cost of avoiding the IMF in 1981 at 0.5 percent of GNP.

Rather than engage in vague innuendo, critics of the IMF should focus on the mistakes that its staff make in their analysis of the situation and in their detailed prescriptions, given the constraints that operate both on the IMF and on the country whose economy is being stabilized. DiazAlejandro offers one such criticism. He suggests that the targeted budget deficit should be defined as the real value of the change in the government's liabilities. Although such an inflation-corrected budget is useful for some purposes, I am doubtful that enough is known about the difference in behavioral responses to legislated tax increases, as compared with an inflation tax on outstanding bonds or other government liabilities (many of which are held by institutions or held abroad) to substitute this budgetary concept for the public sector borrowing requirement preferred by the IMF. Furthermore, intermediate policy targets resulting from agreements between the IMF and the respective country must meet two criteria: the targets must be directly under the control of the government, and they must involve timely and accurate information. An inflation-corrected budget deficit does not meet these criteria. If, 
however, the criticism is meant to imply that in setting budget targets the IMF should allow for the momentum of inflation, that is surely correct. In particular, it can only be considered a blunder if in setting the budgetary target the IMF did not allow for the influence of the February maxi-devaluation on debt-servicing requirements of government and government-owned enterprises with respect to debt denominated in foreign currency, or if it did not allow for the impact on government payrolls of automatic wage indexation.

A targeted drop in the public sector deficit (including state enterprises) from 16.9 to 8.8 percent of GNP in one year seems drastic even without the problem created by a major devaluation combined with indexation of wages and heavy foreign debt. The operative question is whether there was an alternative way to accomplish the same reduction in payments deficit, consistent with the IMF's commitment to currency convertibility for current transactions. I do not know enough about Brazil's economy to be able to answer that question. Most criticisms of IMF stabilization programs do not involve technical suggestions concerning how the objective could have been achieved at lower cost, but rather the suggestion that the IMF-that is, in effect, the international community-should have lent more to the country in question rather than requiring it to adjust so much. In the circumstances of the past three years, and especially since the developments in the private financial market in late 1982 following the Mexican crisis, I concur in this suggestion. But the IMF itself has limited resources. It advisedly proposed a 100 percent increase in quotas in 1982. That this proposal was rejected should be laid at the feet of the major members of the IMF, in particular the United States and several European countries, and not at the IMF as an institution.

Generalized criticisms of the IMF long antedate the past three years. The IMF is typically made a scapegoat for the need to adjust at all, and economists should resist rather than join in such misguided disapprobation.

Diaz-Alejandro concludes with a general lament about current arrangements for rescheduling. His lament comes at a time when many proposals for substantial institutional reform of rescheduling have been put forward, and he therefore implies support for at least some of these proposals. In my view the path of rescheduling that is now under waypiecemeal, case by case, with a number of cliff-hangers-while clearly difficult and uncomfortable, is superior to any alternative path involving 
institutional reform in the current circumstances. Virtually all proposals involve imposing actual or contingent liabilities directly or indirectly on the taxpayers of the major industrial countries and would require parliamentary approval. The prolonged and inevitably acrimonious public debate that would take place in the legislatures of these countries would lead to a drying up of the flow of fresh funds to developing countries that must continue if we are to get through the current world financial crisis at all, as banks' lawyers advise management to make no new loans until the legislative situation clears. A legislated solution is therefore a more dangerous path out of the current woods than the path we are now on. Improvements can be made in existing institutional arrangements, such as rescheduling debt due in the next two or three years rather than merely debt due in the next one to one and a half years, as is now typical. Furthermore, this apparently stand-pat position leaves entirely open the question of long-run reform of methods for handling burdensome international debt. But we can address those with greater leisure once we get through the present crisis.

Rudiger Dornbusch: From 1950 to 1980 Brazilian real GDP did not decline in any single year, and output per capita rose at an average rate of 4.4 percent a year. Since 1980 the debt crisis has changed that performance in a dramatic way. Per capita GDP has been declining at an average rate of 4.1 percent a year and is expected to fall further in 1984 and possibly beyond that. The present decline in output per capita is even more severe than the Brazilian experience in the 1930s and makes the "recession" of the 1960s seem like a minor dip. The decline in per capita GDP in Brazil during these three episodes, measured as percent changes from the peak year, is as follows: ${ }^{1}$

\begin{tabular}{|c|c|c|}
\hline 1929-33 & $1963-67$ & $1981-84$ \\
\hline-2 & -2 & -5 \\
\hline-9 & -2 & -6 \\
\hline-13 & -3 & -12 \\
\hline-13 & 0 & -14 \\
\hline-3 & 1 & $\ldots$ \\
\hline
\end{tabular}

1. Data for years before 1981 were taken from Ralph M. Zerkowski and Maria A. de Gusmão Veloso, "Seis Decades de Economia Brasileira Através do PIB," Revista Brasileira de Economia, vol. 36 (July-September 1982), pp. 331-38. Data for 1981-82 were provided by R. M. Zerkowski. Figures for 1983-84 are projections by the Brazilian authorities. 
Table 1. The Brazilian IMF-3 Program, 1982-84

\begin{tabular}{lrrc}
\hline \multicolumn{1}{c}{ Item } & \multicolumn{1}{c}{1982} & 1983 & 1984 \\
\hline GDP growth (percent) & 1.0 & -3.5 & 0 \\
Inflation (percent) & 95.1 & 160.0 & 55.0 \\
Money growth (percent) & 69.3 & 90.0 & 50.0 \\
$\quad$ Budget deficit (percent of GDP, & & & \\
$\quad$ adjusted for inflation) & 6.0 & 2.7 & 0 \\
Current account (billions of & -16.3 & -6.5 & -6.0 \\
$\quad$ U.S. dollars) & & & \\
\hline
\end{tabular}

Source: Newspaper reports

a. December to December.

The third agreement between Brazil and the International Monetary Fund (IMF-3) in fall 1983 emphasizes monetary and fiscal tightness, as shown in my table 1 above, and thus makes it virtually certain that economic activity will decline even further.

The policy response to the Brazilian payments crisis has been a strategy of "muddling through." Economic activity has been depressed sharply to reduce imports and free foreign exchange to make at least a partial payment on debt service. At the same time the major part of interest payments has been met by increased bank borrowing and some official lending. Currently Brazil pays $\$ 3$ billion in interest to maintain access to $\$ 10$ billion of import financing, without which imports would literally cease. The import-financing requirement makes it worth paying a 33 percent rate of interest.

Two objectives seem to be implicit in recent policies. The first is preventing a Brazilian default and confining the decline in economic activity to a minimum while improving external creditworthiness. The second is, in line with IMF program goals, a dramatic restructuring of aggregate demand through a reduction in the size and deficit of the public sector. In pursuing these objectives, expenditure-reducing policies have been used with no consideration for adjustment and export-led growth through "expenditure switching."

Discussions of the debt problem in early 1983 focused on the debtexport ratio, $B / X$. This ratio will rise to the extent that interest payments exceed the foreign exchange earnings from net exports of goods and services other than interest. At the same time, the ratio will decline to the extent that export earnings in dollars rise. The rate of increase of this debt-export ratio, can be expressed as

$$
\text { Percent change in } B / X=i-S / B-x,
$$


where $i$ is the nominal interest rate; $S / B$, the ratio of the noninterest current account surplus to the external debt; and $x$, the growth rate of dollar export earnings. The interest rate, including fees and risk premiums, is now about 13 percent. Export earnings have been growing thus far at about 7 percent a year, significantly below expectations, and the noninterest surplus is expected to be about 3 to 4 percent of debt. Presently the debt-export ratio is thus rising at a rate of about 2 to 3 percent a year. Continuing world recovery, without significant increases in interest rates, is expected to lead to a stronger reduction in the next year and beyond. But for that algebra to work, as is apparent from the equation above, there is a close race between export growth and nominal interest rates. Some forecasters see Brazilian export earnings growing by 30 percent in 1984, generating great hope of cyclical recovery for the terms of trade and dollar depreciation as well as real growth in industrial countries. That may well be the case, as it was in 1970-74, but perhaps the pattern of the past five years, with export growth averaging only about 10 percent a year, is a better forecast. In that event any improvement in the debt-export ratio will have to come increasingly from an improvement in the noninterest current account. That means either a continuing and even deepening of the recession or a dramatic shift in trade performance due to expenditure-switching policies.

The algebra of debt-export ratios draws attention to a number of issues central to Brazil's debt crisis. First, as Diaz-Alejandro has shown clearly in his paper, a monetarist recession in industrial countries directly exerts an adverse effect on debtors by raising their interest cost while at the same time depressing their export earnings. Dollar appreciation has strongly reinforced this effect. Second, the risk premium charged on Brazilian debt has reached the point of absurdity. Simply because the risk premium is high, the debt-export ratio deteriorates more rapidly and makes the country less creditworthy unless compensating domestic depression increases the noninterest surplus ratio, $S / B$. The increased depression in turn enhances the chances of debt repudiation even though the country is ultimately solvent.

In the early 1970 s Brazil's debt-export ratio was about $2: 1$, which was considered "safe." Today it is about $4: 1$. To return to a safe ratio that removes the threat of recurrent liquidity crises, Brazil will have to take drastic action to expand its export earnings. The growth in dollar-export prices, in Brazilian terms of trade, is largely beyond control and, in the midst of a depression, it would be unwise to rely on the prospect of 
recovery and dollar depreciation abroad. The safe course is to bring about sharp increases in exports by a strong real depreciation that raises, in the medium term, the share of exports in GDP from the current range of 8 to 10 percent to about 15 percent.

A policy of export promotion is also essential if the deficits in the domestic public sector are eliminated and thus aggregate demand, in the short run, is being reduced. The resources released by the public sector and by households whose disposable income declines because of fiscal contraction must be employed in a manner consistent with the external balance constraints. Therefore the real exchange rate must be depreciated to shift resources toward the traded goods sector. Failure to use exports as a source of growth will imply a deterioration of medium-term growth of the kind that has plagued Argentina, for example.

The IMF program does not appear to include provision for a real depreciation, and the devaluation of February 1983 does not go far beyond making up the losses in international competitiveness incurred since 1980. A real depreciation is very costly, of course, because of its short-run adverse impact on inflation and on employment. But because this real depreciation is the central instrument to promote medium-term growth, and hence social stability, it should be given precedence over fiscal stabilization and inflation targets. The alliance between banks, which prefer to "muddle through," and the IMF, which favors fiscal stabilization, does not recognize the need to provide growth if debt repudiation is to be avoided.

Some fiscal stabilization and a reduction of inflation are undoubtedly desirable and perhaps even necessary for a resumption of stable growth. But it is certainly not essential that the stabilization proceed with the vigor scheduled in the IMF-3 program. It would be sensible to postpone some of the fiscal stabilization, in particular some removal of food subsidies, until after the shocks of inflation and unemployment from real depreciation have been absorbed. In the meantime it becomes quite conceivable that domestic restrictive policy, not lack of import financing, is the effective constraint on recovery. That would make the case for a relaxation of monetary policy, placing the responsibility for a successful real depreciation on incomes policy rather than on the depression.

\section{General Discussion}

Jeffrey Sachs argued that an analysis of the debt problem requires projections of the future that are missing from Diaz's paper. These 
should include projections of capacity and demand in the tradable goods sector, relative price changes, and debt burdens, all under a reasonable range of possible policies and world economic developments. He suspected that such projections would reveal that the present debt burden is not exceptionally large under at least some likely future developments. Diaz agreed that such projections are desirable, in principle, but believed that the range of possible outcomes would be very wide.

Many comments addressed the role of the International Monetary Fund in the Brazilian debt problem. In contrast to Diaz's proposal that the client country should choose its own adjustment policies so long as it meets balance-of-payments targets, several discussants defended the IMF practice of setting goals for policy instruments. Peter Kenen stressed that the achievement of a balance-of-payments target does not imply the policies that produced it will continue to have the same result over time. For example, the reduction of imports that can be achieved by running down inventories is not a sustainable balance-of-payments policy. He reasoned that the IMF must be able to monitor policy variables to ensure a viable outcome.

In a related vein, Robert Lawrence observed that, because of lags and J-curve effects, policies appropriate for the longer run can yield perverse balance-of-payments results in the near term. Furthermore, without policy targets from the IMF, there would be too much domestic political pressure to avoid or abandon policies that cause domestic hardships but that are necessary for balance of payments. John Williamson reasoned that policy targets are needed both because necessary policies must be enforced, even if unpopular, and because balance-ofpayments developments are not always controllable. For instance, it would be wrong to place a country in the noncompliance category because an external shock worsens its trade balance. He added that targets for policies have to be realistic and should be adjusted in response to exogenous shocks.

Diaz acknowledged the need for policy changes in the present Brazilian crisis and in general. But he reiterated his objection to the emphasis on policy criteria set by the IMF on two grounds: first, the macroeconomic connection between traditional policy instruments and balanceof-payments objectives is too uncertain; second, the social side effects from various policies will vary greatly from one country to another. Lawrence Krause countered that IMF policy targets were already set with an awareness of the special characteristics of countries. The IMF 
played the vital role of making unpleasant adjustment programs politically palatable. But such programs are based on discussions with groups inside the country that are knowledgeable about the economic situation and about what is politically feasible. In this process, he viewed the IMF as the external force that persuades the country to do the right thing, although the right thing is ultimately determined by a group within the country.

Quite apart from the general question of whether policy targets should be set at all, many participants agreed that present policy targets are too restrictive. Williamson reasoned that the proposed swing toward surplus of 6 percent of GNP in the budget deficit is too restrictive. Charles Schultze agreed, estimating that this is equivalent to a swing of about $\$ 300$ billion in the U.S. structural deficit. James Tobin argued that, in applying such restrictive policy targets for Brazil and other nations with debt problems, the IMF would collectively worsen the world recession, which was an important cause of the debt problems in the first place. He reasoned that the responsibility for getting out of the world debt crisis lay with the major industrial economies, which inevitably would have to be the locomotives of world economic recovery.

Kenen recommended that leverage be applied to the commercial banks to increase the period between debt rescheduling from the present practice of one year to three or four years. This would bring it in line with the three-year commitment of IMF lending programs. George von Furstenberg proposed that risk premiums not be included in the interest rates negotiated at rescheduling. Unlike risk premiums on private loans that are required to build reserves against possible future losses of principal, in a loan to a sovereign country the role of the risk premium is mainly to signal to the country that it is becoming overcommited and that it faces possible curtailment of credit. Once that signal has been received and economic policies have been adjusted so as to contain new borrowing, there is no justification for charging the premium. Negotiated policy commitments that provide reliable means of adjusting financial positions can thus be viewed as a substitute for the risk premiums that might otherwise be required to restrain a sovereign borrower. 